\title{
ON MODERN EDUCATION, STUDENTS AND SOCIAL CHANGE IN THE ISLAMIC MIDDLE EAST*
}

\author{
By BASSAM TiBI
}

The Hellenization of Islam during the Abbasidian era (750-1258) constituted the high point of Islamic civilization in which a highly developed intellectual culture was able to thrive. Not only philosophical and literary but also theological debates and the literature associated with them formed part and parcel of that milieu ${ }^{1}$. Following the Arab-Islamic empire and the decay of its civilization, the region degenerated into a socio-economic and cultural stagnation lasting from the 14 th to the 19 th century. During this period education was monopolized by the Islamic clergy, the Ulema. This monopoly in doctrine and in all other intellectual activities led to a situation in which education came to be reduced to familiarity with the four pillars of religious education: readings from the Koran, Hadith (or handed-down tradition of the Prophet), the Schari'a (Islamic law) and, finally, Arab grammar. The memorizing of the sources of Islamic doctrine ${ }^{2}$ plays a central part in this Islamic education, which thereby impedes rather than promotes the ability to think in terms of problems. It is a form of education which indeed corresponds to the lack of participation in a traditional society dominated hierarchically by the Ulema, the military and the political authorities. As Huntington observes in his latest book: "In traditional societies, political participation is usually not highly valued. Both elite and mass accept the inevitability, if not the positive desirability, of deference, hierarchy, and the existing order of people and things ${ }^{3}$."

The industrial revolution which helped Europe to become the centre of the world also contributed to the technological superiority of its armies over against the Turkish-Ottoman empire for which Islam provided the legitimation. Military defeats led the authorities to conclude that it was advisable "to adopt European weapons, training and techniques", according to the Islam scholar Bernard Lewis, who adds elsewhere that "with European weapons and technology came another importation, European ideas, which were to prove at least equally disruptive of the old social and political order. Until the eighteenth century, the world of Islam had been cut off from almost all intellectual and cultural contact with the West ${ }^{5}$." But already at the start of the 19th century the Sultan's emissaries are to be found travelling in Europe and later using the knowledge acquired there to become even more influential than the Ulema in the Sultan's court. "After the diplomats, the second-and in the long run more important - group of Middle Easterners to appear in Europe were the students . . . by 1818 there were 23 Egyptian students in Europe . . . In the course of the years hundreds of others followed them - the forerunners of the countless thousands that were still to come ... In the universities of Europe in the eighteen twenties, thirties, and forties there was much to learn ${ }^{6}$." Soon a Europeanized education is no longer the exclusive

* Paper submitted to the Third Conference of the Euro-Arab Social Research Group (EASRG) on "Youth, Intelligentsia and Social Chance" in Sliema/Malta, 23-29 March 1980. (The author wishes to thank Dr. Jonathan Cavanagh for editing this paper.)

1 See D. Sourdel, “The Abbasid Caliphate”, in: Cambridge History of Islam (CHI), vol. I, Cambridge 1970, pp. 104-140; see also the articles on "Islamic Society and Civilization" in part VIII, vol. II of CHI, pp. 441-889.

2 On this attitude, see, for example, the textbook of the Egyptian Professor Said I. Ali, Usul at-tarbiyya al-islamiyya (The Origins of Islamic Education), Cairo 1978.

3 S. P. Huntington / J. M. Nelson, NoEasy Choice. Political Participation in Developing Countries, Cambridge/Mass. 1976 , p. 28.

This observation must, however be restricted to more developed, differentiated traditional societies.

4 Bernard Lewis, The Middle East and the West, New York $1966^{2}$, p. 33.

5 Ibid., p. 37.

6 Ibid., p. 39. 
preserve of students abroad; the entire educational system is culturally penetrated by European influences. The part played by students, i. e. the new political elite arising out of this process of westernization, forms the subject of this paper. I deal first with modern education and the new socialization patterns it involves and then proceed to problematize the role of students in the process of social change. The empirical point of reference throughout is the Islamic Middle East.

\section{Modern Education and the New Patterns of Socialization}

In the course of our characterization below of intellectuals as a modern social stratum and as a new political elite in the contemporary Middle East, we do not employ the concept "intellectual" as formally synonymous with "educated". The Islamic Ulema are within their society an educated stratum; but they were and are still not intellectuals in Antonio Gramsci's use of the term. Gramsci uses the concept in the context of the industrial "higher culture": "The mark of the new intellectual may no longer be eloquence, as an external and transitory driving force directed at the emotions and passions; he must rather enter into practical life as a constructor, organizer, 'permanent convincer', not as a mere 'talker'7." For some the fact that these are the views of a European thinker is enough to arouse the suspicion of Europecentricity. Yet we can find a Third World intellectual such as the Malayan social scientist Alatas noting, without any knowledge of Gramsci, the lack of a "functioning intellectual group" as one dimension of underdevelopement and pleading for the emergence of such a group on the grounds that it "should be considered as a development need"". For Alatas, a capacity for posing, definition, analysis and solution of problems is the main characteristic of the intellectual; moreover "the most important distinguishing trait of the non-intellectual is the absence of the will to think and the inability to see the consequence 9 ". Alatas even invokes the spiritual father of Islamic modernism, Afghani, who saw the lack of "intellectual spirit" as one of the prime causes of the backwardness of the Islamic Middle East. "The spirit of inquiry, the sense of the enchantment of intellectual pursuit, and the reverence for scientific and rational knowledge are not widespread in the developing societies ${ }^{10}$." Alatas, who notes the lack of intellectuals in the sense of agents of the technical-scientific culture and pleads for this gap to be filled, takes care to forestall the charge of imitative westernization; "The need for a functioning intellectual group is not a modern Western import. We are not reading Western history into Asian societies ${ }^{11}$." It ought by now to be clear that the type of intellectual described cannot emergef rom a traditional form of education which is uncreative and limited to reproduction and memorization. But the question immediately arises whether or not the modern education originally introduced in the colonial context has been able to produce the new kind of intellectual we have in mind and whether the spread of modern educations has succeeded in creating new patterns of socialization.

As Coleman already pointed out, the establishment of a new system of education in the colonies was primarily geared to the needs of the colonial system ${ }^{\mathbf{1 2}}$. Western education in the colonial context represented one form of imitative west-

\footnotetext{
7 Antonio Gramsci, Philosophie der Praxis. Eine Auswahl, ed. Christian Riechers, Frankfurt/M. 1967, p. 410.

8 Syed H. Alatas, Intellectuals in Developing Societies, London 1977, p. 15.

9 Ibid., p. 16.

10 Ibid., p. 11

11 Ibid., p. 53.

12 See James S. Coleman (ed.), Education and Political Development, Princeton, New Jersey 1965 especially the introduction and part one pp. $35 \mathrm{ff}$.
} 
ernization. Alatas describes it as follows: ,The significance of colonial education lies in its blocking the emergence of an intellectual tradition even in a society with a tradition at an earlier period ... The colonial regime created the habits of horse racing, beer drinking, club life, a taste for Western music, interest in Western sports, and a host of other things. It could have stimulated intellectual interest on a big scale. But it did not ${ }^{13}$." Previous educational patterns were underminded and partially abandoned, new norms were introduced, but the westernized "found themselves without the infrastructure for intellectual activity 14". Such an infrastructure cannot be found in an underdeveloped society.

For political scientists, political socialization is an especially important aspect of the question of the spread of modern education in underdeveloped societies. The empirical studies to which Coleman refers ${ }^{\mathbf{1 5}}$ indicate that in pre-industrial societies the family still remains the fundamental agent of socialization. We must therefore here study the socio-cultural settings in order to see whether patterns of modern education have also brought about new patterns of social intercourse.

In the Islamic Middle East the family is especially crucial in an individual's political socialization. Donald Emmerson has shown in his transnational empirical study how new influences have been most effective in cases where students lived not at home with their parents but in student hostels ${ }^{\mathbf{1 6}}$. However, it is normally students from rural regions who live in such hostels, particularly since universities in underdeveloped countries are only to be found in the larger cities; urban students continue to live at home during their studies. The question of to what extent new values are transmitted can only be answered after an inquiry into the degree of integration of the person concerned in the family system. Stephen Douglas' concepts of continuity and discontinuity in the process of political socialization ${ }^{\mathbf{1 7}}$ - which he developed for the Indonesian context - prove useful here. They help explain the paradox whereby a student of natural science, for example, resorts to prayer or even to magic formulae in order to pass his exams. The introduction of modern science here takes the form of a diffusion, devoid of infrastructure; modern science and technology in peripherical societies "provide readymade knowledge, isolated from any cultural background. Although the methods of science are increasingly adopted, they exist side by side with archaic forms of thought. In developing societies the vast majority, including scientists and educated men, still believe in magic and superstition . . . Hence science and archaic forms of thought are not felt to be in conflict; they are two different things, each valid in its respective sphere ${ }^{18}$ '. This dualism is not perceived by those affected and indeed dominates the attitudes of the superficially westernized. Even students who have studied abroad and have developed new attitudes as a result of their physical separation from the source of their primary socialization usually become rapidly reintegrated into the old family structure once they return and thereby unconsciously bridge the gap between their modern education and archaic ways of thinking and living; the dualism we have referred to persists. This may explain the phenomenon observed by the Malayan intellectual, Alatas, of a lack of intellectual inquiry and spirit among the educated in Third World societies.

\footnotetext{
13 Alatas, op. cit., p. 49.

14 Ibid.

15 See the introduction by Coleman, op. cit., pp. 3-32, here pp. $21 \mathrm{f}$

16 See Donald K. Emmerson (ed.), Students and Politics in Developing Nations, London 1968, conclusions, pp. 390-426, here p. 395.

17 Stephen A. Douglas, Political Socialization and Student Activism in Indonesia, Illinois 1970, p. 18.

18 Alatas, op. cit., pp. $55 \mathrm{f}$.
} 


\section{Students, Political Development and Social Change}

In spite of our reservations concerning the effectivity of new patterns of socialization, we may observe in peripherical societies a new stratum of intellectuals emerging from the modern educational sector and contesting the authority of the representatives of traditional structures. The discontinuities in the processes of political socialization correlate with the structural heterogeneity of the social structures and the socio-cultural fragmentation of society. As was already pointed out in connection with Alatas, the plea for the new type of intellectual and for the modern technical-scientific culture cannot involve an acceptance of Europecentrism. Edward Shils also talks of the worldwide "modern intellectual culture" and says its possession is "vital because it carries with it a partial transformation of the self and a changed relationship to the authority of the dead and the living 19 ".

If one disregards for a moment the discontinuities of political socialization (e. g. the co-existence of a democratic, rational education on the one hand and an authoritarian-traditional family structure on the other), one could conceivably visualize the new education as a positive source of conflicts with authority, producing a rebellion against existing structures. According to Shils, "this has been especially pronounced in those who were brought up in a traditionally oppressive environment and were indulged with a spell of freedom from that environment-above all, freedom from the control of their elders and kinsmen. Once, however, a tradition of rebellion was established among students, it became self-reproducing ${ }^{20}$ ". At the same time Shils points out that the solution of these conflicts often depends on the capacity of the political system concerned to incorporate the rebellious students in the existing cultural institutional system. Such capacities on the part of governments to integrate students fired into rebelliousness by new patterns of political socialization are normally minimal in peripherical societies where the resources of the political system are strictly limited. Emmerson calls this problem "students' occupational frustrations" and defines it as follows: "One of the sources of this insecurity is the contrast between what the student wants out of life and what he expects to get, for it is here that he feels most deeply the dislocative effects of socioeconomic change . . . he may be able to identify more fully with calls for sweeping, radical change because he feels he has nothing to lose and everything to gain by shaking up the status quo ${ }^{21}$." In my own study of Iranian students I accepted this approach while introducing some modifications into the discussion ${ }^{22}$. The Iran scholar, Jacobs, had already pointed in 1967 to the political significance of Iranian students as a political potential, when he wrote "The ideological control of Iranian students overseas is considered a special problem by the political authority. For such students may leave Iran to study abroad at too early an age; that is, at an age when they morally are vulnerable to a way of life that is radically different from that to be found in Iran, and at an age before they have interiorized the Iranian religious, social, and cultural traditions to the extent that they forever will be bound to Iran and the Iranian way of doing things. Also, as returnees, they may not adjust to the realities of Iranian society. For they (too often) expect as a right, prestigeful occupational opportunities (usually in the political apparatus, of course) comparable to what they have become accustomed to abroad, which do not exist in Iran. And when they do not receive these opportunities,

\footnotetext{
19 Edward Shils, "The Intellectuals in The Political Development of the New States", in: John H. Kautsky (ed.), Political Change in Underdeveloped Countries, New York 1967, pp. 195-234, here p. 199.

20 Ibid., p. 204.

21 Emmerson, op. cit., pp. $409 \mathrm{f}$

22 See B. Tibi, "Die iranischen Studenten im Ausland als ein gesellschaftliches Veränderungspotential und ihre Stellung im politischen System", in: Orient, vol. 20 (1979), no. 3, pp. 100-108.
} 
they grumble and create dissatisfaction and political unrest in the society ${ }^{23}$." Yet the Iranian case illustrates that students' frustrations may not be reduced solely to the category of occupational worries, since Iran under the Shah had a political system with extensive resources, capable of integrating intellectuals at least in the economic sense. Via their modern education, students - especially those who study abroad (see below) - may perceive that modern, structurally and functionally differentiated societies permit personal freedoms which are unknown in traditional, underdeveloped societies. As I was able to show, the Iranian Shah regime was capable of integrating students occupationally but not politically ${ }^{24}$. Hence the occupational frustrations of students in underveloped societies ought not to be over-estimated as determinants of their behaviour.

Emmerson's framework proposes three levels of analysis for investigations into the behaviour and attitudes of students in underdeveloped societies: 1 . Individual biographical variables; 2 . The institutional and academic discipline variables for the university concerned; 3. The more extensive, societal level of the given context of political and social change ${ }^{25}$.

At the individual, biographical level, data are to be collected concerning age, sex, social origin, family environment and also the family's religious affiliation, which may then be aggregated to permit generalizations. At the second level, distinctions must be made not only between disciplines but also between the varying degrees of westernization of the university institution concerned. Such distinctions are important even within a single country, e.g. in Egypt where the political behaviour of students at the Islamic Azhar University differs radically from that of students at Ain-Shams University. Another important distinction is between students at local and students at European or North American universities; a distinction with which we deal in the following section. At the third level of analysis, individual country case studies are required.

Emmerson rightly stresses that the study of the political role played by students in political development in the Third World is an extremely complex matter because a student acts and interacts at two levels: he is simultaneously a member of a traditional family and a participant in a modern institution, the university. "His age, religion, and personality, the proximity, social origins, and political attidudes of his family, the location, auspices, and quality of his university, his career preparations and perceived life chances, the politicians who proselytize him, the balance of stability and change in his nation - all these factors define the terms of a student's entrance into, or avoidance of, the political realm ${ }^{26}$." The student acts within a socio-culturally and socio-economically structurally heterogeneous society; his political behaviour is determined by this cultural fragmentation.

\section{Study abroad and Students as a Polarizing Force in Social Conflict}

We mentioned at the start of this paper how the first Islamic study groups in Europe at the beginning of the 19th century largely contributed to the establishment of Western-European cultural influences. The Arab-American historian, Sharabi, who has studied this phase, wrote: "The rise of the intellectuals and the elaboration of ideological functions must be seen as a manifestation of the process of education and enlightenment brought about by increas-

\footnotetext{
23 Norman Jacobs, The Sociology of Development. Iran as an Asian Case Study, New York 19672, p. 234.

24 See my article on Iranian students in footnote 22, p. 106.

25 Emmerson, op. cit., p. 392.

26 Ibid., p. 415.
} 
ing contact with Europe ${ }^{27}$." The Islamic scholar who accompanied the first big Egyptian study group to Paris in 1826 in his capacity as Imam (religious prayer-leader), Rifa' a Tahtawi, later became - following his return to Egypt - a pioneer of cultural westernization in the whole of the Middle East. His biography records problems of students abroad which are no less relevant today. Such a student is a man living between two cultures which have developed differently, a man enlightened by the alien culture and seeking to adopt elements of it without wanting to give up his own culture. In his Paris diary, which has been and still is widely read and reprinted countless times, Tahtawi wrote: "Naturally I only accept that which is not in contradiction to the text of our Islamic law . . .28." Tahtawi was enabled by his studies in Paris - which he carried out alongside his function as Imam - to become an intellectual because, in contrast to other Islamic scholars who, in Tahtawi's words, restricted themselves to writing "commentaries and super-commentaries" on the religious texts handed down by tradition, Tahtawi himself risked opening himself mentally to new experience. He already noted the difference between the traditional scholar and the modern intellectual in his Paris diary, when he wrote: "When somebody is referred to in France as a scholar, he is not a religious expert but somebody who is well-informed in one of the other sciences. It is not difficult to observe the superiority of these Christians in the sciences and hence also to observe that many of these sciences do not even exist in our countries ${ }^{29}$." The Oxford scholar, Albert Hourani, who has written the most comprehensive and informative work to date on the history of modern Arab-Islamic ideas, evaluates Tahtawi's ideas as follows: "Tahtawi's ideas about society and the state are neither a mere restatement of a traditional view nor a simple reflection of the ideas he had learnt in Paris. The way in which his ideas are formulated is on the whole traditional: at every point he makes appeal to the example of the Prophet and his Companions, and his conceptions of political authority are within the tradition of Islamic thought. But at points he gives them a new and significant development ${ }^{30}$." Tahtawi is a very clear example of an intellectual who begins as a student abroad, becomes a cultural modernizer, and through his westernization comes to live in two unreconciled worlds; he is a product of contemporary processes of acculturation ${ }^{31}$.

Gradually, studies abroad in western countries by students originally socialized in an Islamic context come to acquire political as well as cultural significance. In other words, those who study abroad do not only have a social role to play as cultural mediators in the acculturation process; they also become a political factor. In the West they learn the norm and praxis of political opposition and are thereafter no longer prepared to accept the existing order uncritically. University students, "particularly those who have studied abroad 32 ", are reckoned by Huntington to be the most modern and progressive groups in an underdeveloped, traditional or transitional society. Huntington even attributes students a similar significance to that of officers, particularly since both the military and westernized students are "the two most active social forces in a praetorian system at its middle level of development ${ }^{33}$ ".

Underdeveloped societies, whose political system may be categorized here in Huntington's terms as praetorian, i.e. non-instutitionalized, lack an institutional framework for the set-

\footnotetext{
27 Hisham Sharabi, Arab Intellectuals and the West: The Formative Years, 1875-1974, Baltimore-London 1970, p. 2.

28 See the German Translation of Tahtawi: at-Tahtawi in Paris. Ein Dokument des arabischen Modernismus aus dem frühen 19. Jahrhundert, translated with an introduction by Karl Stowasser, Ph. D. Thesis, Münster 1968, p. 65.

29 Ibid., pp. $199 \mathrm{f}$.

30 Albert Hourani, Arabic Thought in the Liberal Age, London 1962, p. 73.

31 See B. Tibi, "Akkulturationsprozesse im modernen Orient", in Neue Politische Literatur, vol. 15 (1970), pp. 77-84, and most recently B. Tibi, "Akkulturation und interkulturelle Kommunikation", in: Gegenwartskunde, vol. 29 (1980), no. 2, pp. 173-190.

32 Samuel P. Huntington, Political Order in Changing Societies, New Haven $1969^{2}$, p. 201.

33 Ibid., p. 210
} 
tlement, mediation and channelling of conflict. Direct political action is thus the most significant form of political praxis. Student demonstrations and riots are therefore more important as forms of direct political action in praetorian societies. Through such actions, students may polarize social forces and thereby indirectly contribute to the downfall of a government, as Huntington pointed out back in $1968^{\mathbf{3 4}}$, long before events in Iran confirmed the thesis with the ousting of the Shah. Students can polarize and thus assist latent social conflicts to become manifest. Their actions may be decisive in bringing down a government, but never go beyond these negative actions and act positively. For "by their very nature, students are against the existing order, and they are generally incapable of constituting authority or establishing principles of legitimacy. There are numerous cases of student and religious demonstrations, riots, and revolts, but none of student governments ${ }^{35}$ ".

If one recalls recent events in Iran and the fact that students there have not always played a modernizing role, the question arises whether it may still be maintained that students are one of the decisive social forces in the process of modernization. The Iran scholar, Jacobs, quoted above, pointed out in the 1960's that although students threaten the existing order they ought not automatically to be considered elements of the modernization process. "Regardless of the negative trouble certain students have created, and it has been considerable, yet, it must not be thought that these students are necessarily agents of positive change that many over-enthusiastic economists, political scientists, and sociologists have made them out to be. This premise does not preclude the fact that these students are, or may be, agents of "modernization" and other innovations ..., which do not challenge the essentials of the basic Iranian institutional structure ${ }^{36}$."

We must here recall what was said earlier about the political socialization of students in underdeveloped societies and remember that for these students - including those who have studied abroad - the family remains the fundamental source of socialization, which is why westernization remains superficial. For the society in which these students live and act is also not a modern society. In my study of modern-day Islam I have sought to show how the westernization process in the Middle East has been a matter primarily of norms ${ }^{37}$. Western systems of norms were introduced in the years described as "formative" by Sharabi ${ }^{\mathbf{3}}$, but the society has not become structurally modernized or industrialized. Western education leads to cultural anomy, as I illustrated in the study mentioned.

Thus my references in this paper to westernized students in the Islamic Middle East as a modernizing elite have to be seen in the context of what has been said above about political socialization and about the normative rather than structural form which westernization has taken. If we locate students or their social and political activities within this wider context, we may conclude by sharing Emmerson's view of westernized students: "His ties to family and community are not somehow magically severed by matriculation. Nor is he automatically an enthusiast in the vanguard of change. In part a product of modernization, he is psychologically exposed to its dislocations ${ }^{39}$."

\footnotetext{
34 Ibid., p. 213.

35 Ibid., p. 239.

36 Jacobs, op. cit., p. 234

37 See B. Tibi, "Islam und sozialer Wandel im modernen Orient", in: Archiv für Rechts- und Sozialphilosophie, vol. 65 (1979), no. 4, pp. 483-502.

38 Sharabi, op. cit.

39 Emmerson, op. cit., p. 415.
} 


\section{Islam and Western Ideologies \\ By ZEHRA ÓNDER}

Islamic countries are at present in a crisis. This crisis has many dimensions: a cultural one (with its historical perspective), an ideological, a social, a psychological, an economic and also a political one. The Islamic revolution in Iran is the recent expression of this crisis. After centurylong influence of colonial powers the Islamic people are now on the way of indentity-finding. Islam as a religion is not new, but its dynamics of mobilization today. Under foreign predominance Islam in the course of history has lost very much from its dynamics and became, especially after the invasion of Turco-Tatarian people (nomadic tribes of Central Asian steppes) of Afghanistan, North-India, Iran, Asia-Minor and nearly all the Arab world (Ottoman empire) a power-ideology (Herrschaftsideologie). That development had devasting and lasting consequences on the Middle East, which was at that time culturally, socially and economically highly developed. The intellectual life in these countries was paralysed and paved the way for the later stagnation.

Parallel to this development, Europe experienced a huge cultural, ideological, social, technical, economical, military and political rise. This development widened the gap between the Middle East and Europe. While in Europe secular philosophies presented alternatives to religion, the Islamic world grew stiff through the lack of new impulses. To close the gap between occident and orient, the elites adopted Western concepts without any criticism and fell into cultural dependency. Islamic masses remained however without understanding of foreign concepts (capitalist, communist or conglomerates of those), because the values and norms were neither adequate to their presuppositions nor to their needs. The dualism as a result of this development on nearly all levels caused the identity-crisis. Only when Islam as an authentic instrument of development is generally accepted and developed, the ideological confusion within the Islamic-Arabic world on the one hand and the identity-crisis on the other hand, could be overcome.

\section{On Modern Education, Students and Social Change in the Islamic Middle East By BASSAM TiBI}

This paper starts from the thesis that modern education, inasmuch as it introduces new patterns of socialization, is one of the factors contributing to the dissolution of traditional social structures. Through modern education traditional societies are being westernized, i.e. traditional education which is largely limited to the memorization of learned sources is thus also being removed. Based on Gramsci's definition of the intellectual this paper differenciates between , learned“ and ,,intellectual“. The intellectual does not memorize like the traditional learned; rather, the intellectual's thinking is problem-oriented.

In Islamic societies westernized intellectuals have been the agents of social change since the 19 th century (the generation of Tahtawi). Yet, inasmuch as the oriental family still remains a very important agent of socialization also in transitional societies, the effects of the new patterns of socialization must be seen in a modified way. This paper develops the thesis, that modern education is introduced into an underdeveloped society which is lacking the infrastructure for the new institutions. This results in an only partial modernization, i.e. in a coexistence of modern and traditional elements in one and the same structure, a structure which must be defined as heterogeneous. 
The thesis of structural heterogeneity pertains also to education: Muslim students with a modern socialization live in a traditional familiy-structure. Thus they suffer from a dual, heterogeneous psycho-social disposition. The reference to the psycho-social dualism in education finally leads to a modification of the thesis, that modern students are the main agents of social change. 